\title{
鶟肉の含窒素化合物に就て
}

農學博士 吉 村 清 份

(大正十五年十月十九日受理)

從承肉エキスの化學的組成につきての䂙究成績は頗る多しこ踓も鵎肉の化學的

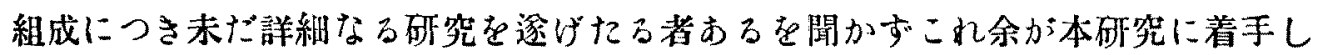
たる所以なりとす

本研究に供したる肉は雜種鵎より探集し脂昉組織を略除去したるものにして次 の組成を有す

$\begin{array}{lll}\text { 水 } & \text { 分 } & 68.908 \% \\ \text { 乾 } & 31.092 \%\end{array}$

乾物百分，中

粗蛋白質(全筀素 $\times 6.25$ ) 69.525

粗 脂 肪 32.706

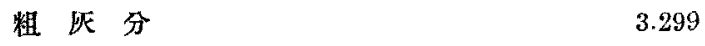

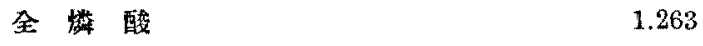

水溶性燐酸 $\quad 0.777$

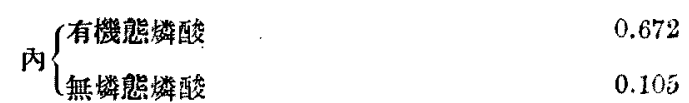

全㱖素田 11.124

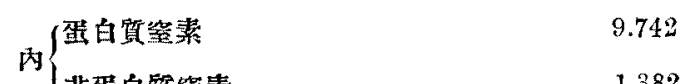

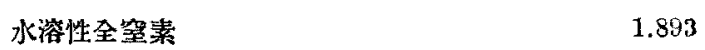

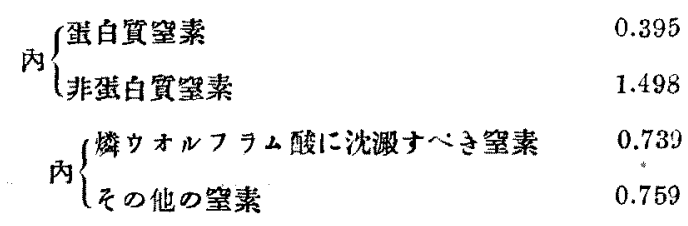

露驗の 部

I. クレアチンの分離

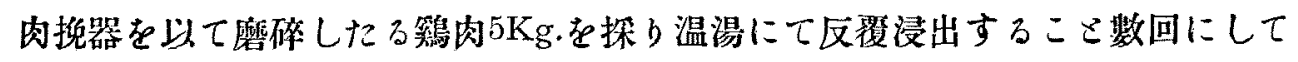

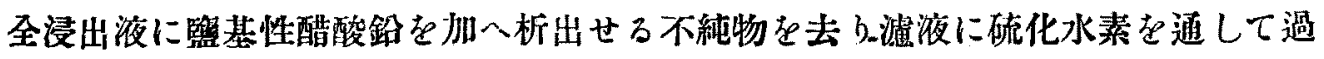




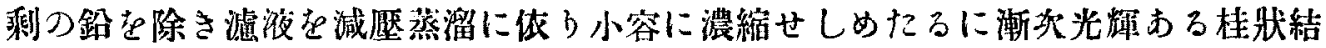
唱を析出しその收量 $6 \mathrm{~g}$. :達したり本品は水に溶け中性反哕を是し毛細管內にこ れを非すれば $225^{\circ} \mathrm{C}$ 內外にて分解す本品の一定量を探り結晶水を定量したるに その結果下の如し

$$
\begin{array}{lrrr}
0.1474 \mathrm{~g} . & \text { 供 試 品 } & 0.017 \mathrm{gg} \text {. 水 } & =12.08 \% \text { 水 } \\
\text { 計 算 数 (Kreatin： } & \mathrm{C}_{4} \mathrm{H}_{2} \mathrm{~N}_{3} \mathrm{O}_{2}+\mathrm{H}_{2} \mathrm{O} \text { ) } & & 12.08 \% \text { 水 }
\end{array}
$$

又本品の一定量を探り真空内 $100^{\circ} \mathrm{C} に$ 晖燥したる伐窒素を定量したるに次の結 果老得吅b

$$
\begin{aligned}
& 0.0994 \mathrm{~g} \text {. 供 試 品 } 0.0318 \mathrm{~g} \text {. 整素 }=32.00 \% \text { 空 素 } \\
& 0.0906 \mathrm{~g} \text {. 供 武 品 } 0.0289 \mathrm{~g} \text {. 整素 }=31.89 \% \text { 素 } \\
& \text { 計 算 数 (Kreatin： } \mathrm{C}_{4} \mathrm{H}_{0} \mathrm{~N}_{3} \mathrm{O}_{2} \text { ) } 32.06 \% \text { 空 素 }
\end{aligned}
$$

\section{II. 燐ウオルフラム酸沈澱}

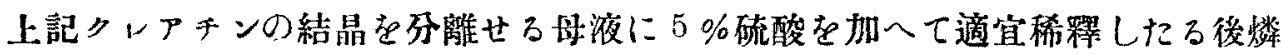
ウオルフラム酸を以て沈澱せしめたり

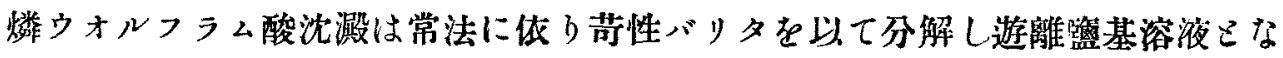
し硝酸にて中和したる後确酸銀液を加一たるに黃褐色の沈澌を析出したり

\section{（a）硝酸銀沈澱（プリン盞基）}

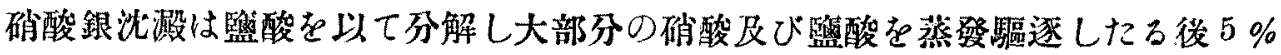
硫酸寺加へて適宜の容量さなし更に燐りオルフラム酸を加へて沈澱せしめたり。

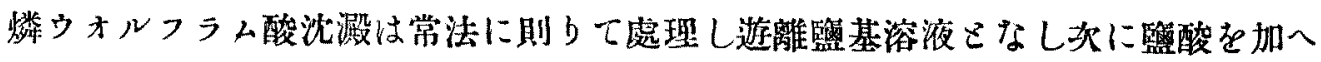

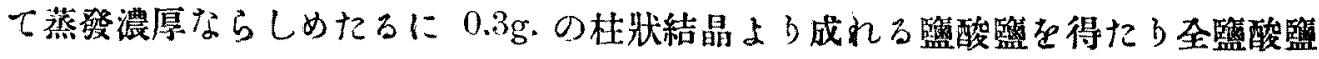
の水溶液にビクリン酸ナトリウムの飽和溶液を加入たるに二種の結晶より成れる ピクリン酸監を析出したりその一は針狀結晶にして水に極めて溶解し難く毛細管 內にこれを熱すれば $280^{\circ}$ 内外に於て熔解するなごアデニンピクラートに一致す るを知り得たり他の一は橙黄色紡垂狀若くは柱狀結晶より成り此較的水に浴け易

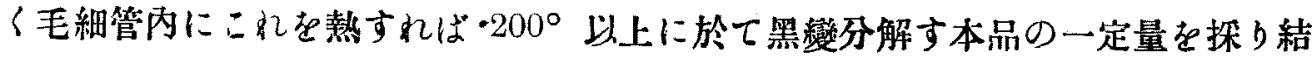
晶水並にビクリン酸を䇥量したb

$0.1540 \mathrm{~g}$. 供 試品 $0.0079 \mathrm{~g}$. 水 $=5.13 \%$ 水

計算坡(Hypoxanthinpikrat: $\left.\mathrm{C}_{5} \mathrm{H}_{4} \mathrm{~N}_{4} \mathrm{O} \mathrm{C}_{6} \mathrm{H}_{8} \mathrm{~N}_{3} \mathrm{O}_{7}+\mathrm{H}_{2} \mathrm{O}\right) 4.70 \%$ 水

$0.1460 \mathrm{~g}$. 供試品 $0.0910 \mathrm{~g}$. ビクリン酸 $=62.33 \%$ ビクリン酸

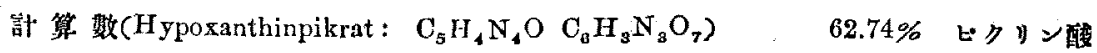




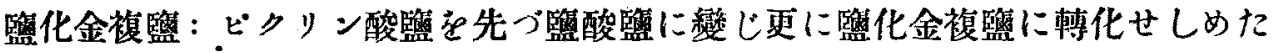
るに黄色菱柱狀の結晶を得けり本品は毛細管內にこれる熱すれば 240一255に於 $\tau$ 黑變分解す

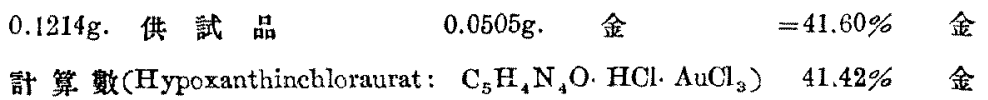

(b) 硝酸銀及びバリタ沈澱

前項硝酸銀沈筂の滤液に更に過量の硝酸銀を加へたる後過剩の苛性バリタの濃 厚液を加へたるに暗褐色の沈澱を多量に析出したり該沈澱は監酸を硫酸さを以て 處理しその濾液を蒸發して大部分の監酸を驅逐し去りにる後再び燐ウォルフラム 酸を以て沈澱せしめてb斯くして得てる燐ウォルフラム酸沈澱は常法に依り节性

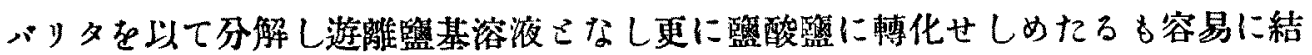
晶を析出せす仍てこれを適宜の水に溶かしビクリン酸ナトリウムの濃厚液を加へ しに橙黄色柱狀結晶を多量に析出しその收量約 $1.0 \mathrm{~g}$. に達したり本絬晶は水に溶 解し難く毛細管內にこれを熟すれば198一200に於て溶解す本品の一定量を探り $100^{\circ}$ に乾燥しピクリン酸を定量したり
$0.1550 \mathrm{~g}$. 供 試 品
$0.1170 \mathrm{~g}$ ・ヒクリン酸
$=75.49 \%$ ビクリン繂
計 算 数(Mathylguanidinpikrat: $\mathrm{C}_{2} \mathrm{H}_{7} \mathrm{~N}_{3} \cdot \mathrm{C}_{8} \mathrm{H}_{3} \mathrm{~N}_{3} \mathrm{O}_{7}$ ) $75.83 \%$ ピクリン酸

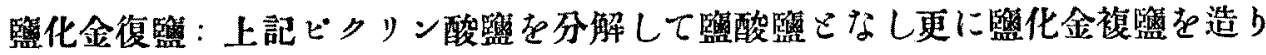
たるに黄色柱狀結品を得たり本品は冷水に較々溶け㘗く毛細管內にこれを熱すれ ば $200^{\circ}$ に於て熔解す

$\begin{array}{llllll}0.4400 \mathrm{~g} . & \text { 供 試 品 } & 0.2096 \mathrm{~g} . & \text { 金 } & =47.64 \% & \text { 金 } \\ 0.2564 \mathrm{~g} . & \text { 供 試 品 } & 0.1221 \mathrm{~g} . & \text { 金 } & =47.62 \% & \text { 金 } \\ \text { 計算 数(Methylguanidinchloraurat: } \mathrm{C}_{2} \mathrm{H}_{7} \mathrm{~N}_{3} \cdot \mathrm{HCl} \cdot \mathrm{AuCl}_{3} \text { ) } & 47.73 \% & \text { 金 }\end{array}$

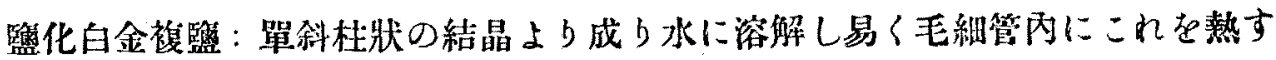
れぱ $189-190^{\circ}$ に於て分解す

$0.1180 \mathrm{~g}$. 供試 品 $0.0414 \mathrm{~g}$. 白金 $=35.09 \%$ 白金

計算 数 [Metblyganidinchlorplatinat: $\left.\left(\mathrm{C}_{2} \mathrm{H}_{7} \mathrm{~N}_{3} \cdot \mathrm{HCl}\right)_{2} \mathrm{PtCl}_{4}\right] 35.06 \%$ 白 金

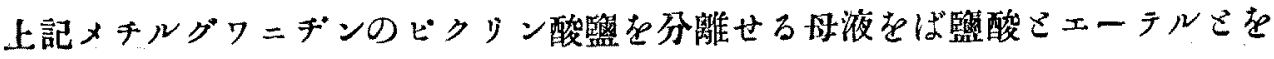

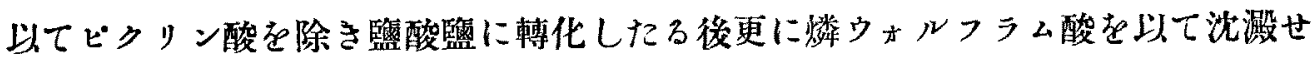
しめ以下常法に則り遊離醖基溶液を造り減壓の下に濃縮せしめたるに漸次針狀結

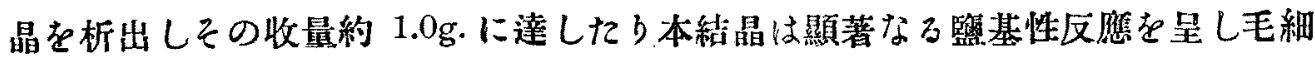


管內にこれを熱すれば $243-246^{\circ}$ に於て熔解す本品の一定量を探り與空內 $100^{\circ}$ に乾燥し堂素を定量したb

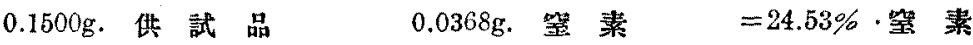

$$
\begin{aligned}
& \text { 計 算 數 (Carnosin： } \mathrm{C}_{2} \mathrm{H}_{14} \mathrm{~N}_{3} \mathrm{O}_{3} \text { ) } 24.77 \% \text { 咩 素 }
\end{aligned}
$$

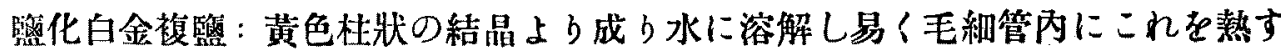
れば $213-214^{\circ}$ に於て熔解す本品の一定量を探り奥空内 $100^{\circ}$ に乾燥し白金を定 量したり

$$
\begin{aligned}
& 0.1201 \mathrm{~g} \text {. 供武品 } 0.0369 \mathrm{~g} \text {. 白金 }=30.72 \% \text { 白金 } \\
& \text { 計算數 (Carnosinchlorplatinat: } \mathrm{C}_{9} \mathrm{H}_{14} \mathrm{~N}_{4} \mathrm{O}_{3} \cdot 2 \mathrm{HCl} \cdot \mathrm{PtCl}_{4} \text { ) } 30.61 \% \text { 白 金 }
\end{aligned}
$$

（c）俏酸銀及びバリタ泝澱の滤液

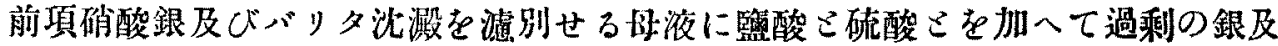
びバリウムを除きたる後更に燐ウォルフラム酸を以て沈澱せしめてり燐ウォルフ ラム酸沈澱は节性バリタを以て分解し遊離監基溶液さなしこれに過量の監酸を加

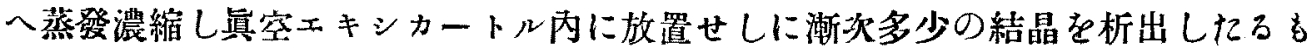
全部結晶するに至らす仍て十分乾燥せしめてる後無水酒精を以て處理したるに不 溶解の結晶 $3.7 \mathrm{~g}$. を得たり

然水酒精に不溶 監酸䀍

無水酒精に不溶血酸監は多少無機監を混せしに由りメチルアルュールを以て處

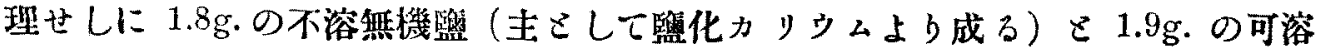

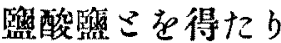

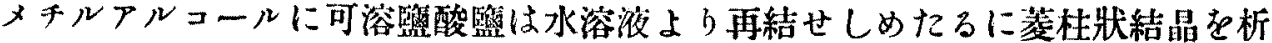
出し器水酒精に溶け難く毛細管內にこれを熱すれば258一2590にて熔解す本品の 一定量を探了黄突內 $100^{\circ}$ に乾燥したる後掌素を定量したb

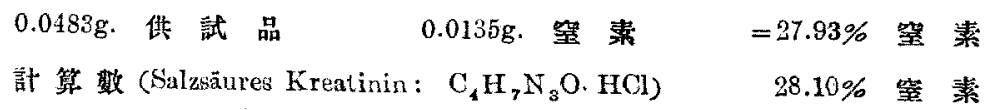

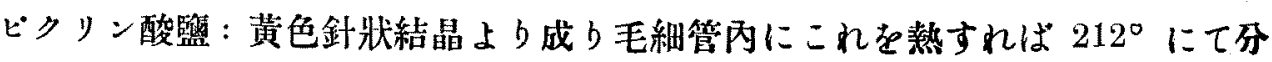
解す

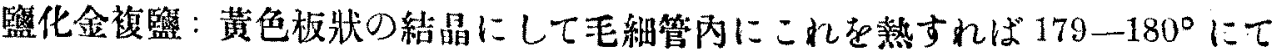
熔解す

$$
\begin{array}{llllll}
0.1350 \mathrm{~g} . & \text { 供 試 品 } & 0.0588 \mathrm{~g} . & \text { 金 } & =43.56 \% & \text { 全 } \\
0.0914 \mathrm{~g} \text {. 供 試 品 } & 0.0100 \mathrm{~g} . & \text { 金 } & =43.76 \% & \text { 金 }
\end{array}
$$


計算轵(Kreatininchloraurat： $\mathrm{C}_{4} \mathrm{H}_{7} \mathrm{~N}_{8} \mathrm{O} \cdot \mathrm{HCl} \cdot \mathrm{AuCl}_{3} \quad 43.51 \%$ 金

無水酒精に可溶籃 酸監

（1）ビクリン酸監 上記酒精に可溶監酸監はエキシカートル內に放置せしも 容易に結晶を析出せず仍て適宜の水に溶解しビクリン酸ナトリウムを加入たるに 多量の針狀結晶在析出りその收量 $1.3 \mathrm{~g}$.に達したり該ビクリン酸監存水溶液より

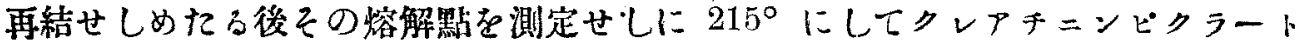
のそれに一致するを知り得たり本鼠の一定量を探り真空内 $100^{\circ}$ に乾燥しビクッ ン酸を定量したり

$$
\begin{aligned}
& 0.1660 \mathrm{~g} \text {. 供 試 品 } \quad 0.1096 \mathrm{~g} \text {. ピクリン酸 }=66.02 \% \text { ビクリン酸 } \\
& \text { 計算教(Kreatininpikrat： } \mathrm{C}_{4} \mathrm{H}_{7} \mathrm{~N}_{3} \mathrm{OC}_{6} \mathrm{H}_{3} \mathrm{~N}_{3} \mathrm{O}_{7} \text { ) } 66.98 \% \text { ビクリン酸 }
\end{aligned}
$$

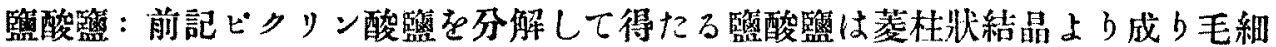
管內にこれを熱すれば $257^{\circ} に て$ 熔解す

監化金複監：黃色板狀結晶より成り毛細管內にこれを熱すれば $175-176^{\circ} に て$ 熔解す

$$
\begin{aligned}
& 0.1896 \mathrm{~g} \text {. 供武品 } 0.0830 \mathrm{~g} \text {. 金 }=43.78 \% \text { 金 } \\
& \text { 計算 (Kreatininchloraurat： } \mathrm{C}_{4} \mathrm{H}_{7} \mathrm{~N}_{3} \mathrm{O} \cdot \mathrm{HCl} \cdot \mathrm{AuCl}_{3} \text { ) } 43.51 \% \text { 金 }
\end{aligned}
$$

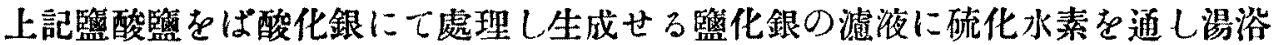
上に於て丵發涸的せしめたる後これを水にて取り滤液を蒸發濃縮せしめたるに柱 狀結晶を析出したり本結晶を水に溶解しこれにビクリン酸の水溶液を加へ更に击 性曹達液の二三滴を加ふるこきはクレテチニンに特有なる血赤色を現はす

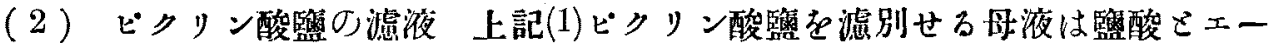

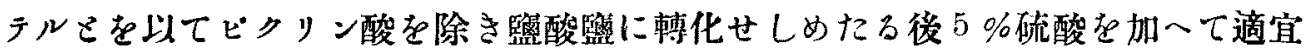
の容量さなし更に燐ウォルフラム酸を以て沈澱せしめ以下常法の如く发理して遊 疁監基溶液を造り低壓の下に蒸發濃厚ならしめ真空管ェキシカートル內に放置せ しに漸炏針狀結晶を析出しその收量 2.6g.に達したり本品は水に溶解し易きも酒

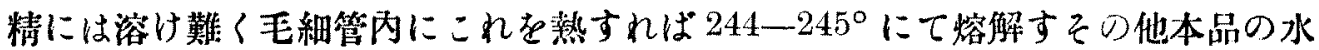
溶液は强監基性反應を呈する等その性狀すへてカルノシンに一致す

本品の一定量を探り真空內 $100^{\circ}$ に䓽燥したる後学素を定量したるにその結果 下゙の如 $L$

$$
\begin{aligned}
& \text { 0.0861g. 供試品 } 0.02125 \mathrm{~g} \text {. 空素 }=24.68 \% \text { 䟚素 } \\
& \text { 計算数 (Carnosin } \mathrm{C}_{5} \mathrm{H}_{14} \mathrm{~N}_{4} \mathrm{O}_{3} \text { ) } 24.77 \% \text { 紫 素 }
\end{aligned}
$$


硝酸鹽：無色針狀結晶より成り $215^{\circ}$ に於て螾解す

$0.1520 \mathrm{~g}$. 供 試品 $0.0327 \mathrm{~g}$. 硝 酸 $=21.51 \%$ 硝 酸

計算數(Carnosinnitrat： $\mathrm{C}_{9} \mathrm{H}_{14} \mathrm{~N}_{4} \mathrm{O}_{8} \cdot \mathrm{HNO}_{3}$ ) $21.80 \%$ 硝 酸

監化白金複鹽：黃色柱狀結晶より成り $212-214^{\circ}$ に於て揢解す

$0.1380 \mathrm{~g}$. 供試品 $0.0425 \mathrm{~g}$. 白金 $=30.80 \%$ 白金

計算數 (Carnosinchlorplatinat: $\mathrm{C}_{0} \mathrm{H}_{14} \mathrm{~N}_{4} \mathrm{O}_{3} \cdot 2 \mathrm{HClPtCl}_{4}$ ) $30.61 \%$ 白金

銅監：濃青色板狀結晶にして毛細管內にこれ熱すれば $220^{\circ}$ 内外にて黑變分 解す
$0.1310 \mathrm{~g}$. 供 試 品
$0.02686 \mathrm{~g}$
$=20.50 \%$
銅
計算数 (Carnosin Kupfer: $\mathrm{C}_{0} \mathrm{H}_{14} \mathrm{~N}_{4} \mathrm{O}_{3} \cdot \mathrm{CuO}$ )
$20.81 \%$ 銅

斯の如くカルノシンがアルギニン並にリシン兩フラクションに現はれたるは蓋 しカルノシンは硝酸銀及びバリタに上りて不溶解性の銀監さして沈澱せらるっる 試樂過剩なるときはその一部溶解するがためなる心゙し

今 $5 \mathrm{Kg}$. 鴙肉よb實際分離し得たる含等素化合物の量を示せば下の如し

$\begin{array}{ll}\text { クレアチン } & 6.0 \mathrm{~g} . \\ \text { アデニン } & \text { 少量. } \\ \text { とボキサンチン } & 0.14 \mathrm{~g} . \\ \text { メチルグワニダン } & 0.24 \mathrm{~g} . \\ \text { クレアチンン } & 2.0 \mathrm{~g} . \\ \text { カルンシン } & 3.6 \mathrm{~g} .\end{array}$

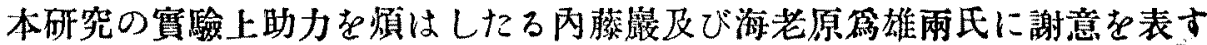
（大正十五年六月） 